\title{
The weighted product method and portfolio assessment in ranking student achievement
}

\author{
Andi Tenri Sumpala a, ${ }^{\text {, }}$; Muh. Nurtanzis Sutoyo ${ }^{\text {a, }}$; Huzain Azis ${ }^{\text {b, } 3 \text {; Fadhila Tangguh Admojo }}{ }^{\text {c, } 4}$ \\ ${ }^{a}$ Universitas Sembilanbelas November Kolaka, Jl, Pemuda, Kolaka, 93511, Indonesia \\ ${ }^{b}$ Universitas Muslim Indonesia, Jl. Urip Sumoharjo, Makassar, 90231, Indonesia \\ 'STMIK PalComTech, Jl. Jend. A. Yani, Ulu Palembang, 30262, Indonesia \\ ${ }^{1}$ foleta.21@gmail.com; ${ }^{2}$ mns.usn21@gmail.com; ${ }^{3}$ huzain.azis@umi.ac.id; ${ }^{4}$ fadhila.tangguh@palcomtech.ac.id \\ * Corresponding author
}

Article history: Received March 30, 2021; Revised July 04, 2021; Accepted July 04, 2021; Available online August 07, 2021

\begin{abstract}
The learning process has a correlation with learning achievement which can be shown through the marks given by a teacher to students from several fields of study. The ranking of student learning achievements performed by the school refers to the grades of the subject is important for the SNMPTN (National Selection for State Higher Education). To determine student achievements, the method used in the current study is the weighted product. If the results of student ranking using the WP method have the same value, then a portfolio assessment is used. Of the 127 student achievement ratings, there were seven people who had the same Vector value. Then, the seven people who have the same vector value were graded using portfolio assessment. The results showed that the implementation of the WP method and portfolio assessment could determine the ranking of student achievement.
\end{abstract}

Keywords: Weighted Products; Portfolio; Learning achievement

\section{Introduction}

The progress of a country is supported by the advancement of education to increase reliable Human Resources (HR). Education seeks to cultivate skilled individuals in various fields such as economics, education and other related fields. Article 1 paragraph 1 of the Law on the National Education System Number 20 of 2003 states that education is a deliberate and organized effort to build a learning environment and learning process in order to realize the interests of themselves, society, nation and state, where students actively increase their capacity for spiritual religious strength, self-control, personality, intelligence, noble values and skills needed.

The end product of a learning process that includes student learning and teaching experiences is learning achievement. The results of learning achievement can be proven through grades given by a teacher from several subjects that have been studied by students. In learning, a student must always expect maximum achievement or results. To achieve the maximum grade, student achievement is strongly influenced by various factors. The involvement of teaching staff (teachers) is one of the main factors that have a significant influence on learning achievement. Therefore, the quality of teachers should be paid more attention [1].

Ranking school based on the grades of the subject is one of the requirements in taking the National Selection for State Higher Education (SNMPTN) which can be conducted by the school based on the grades of the subjects. If students have the same score, the school can use other criteria in the form of academic achievement. So, it is important for schools to complete the School and Student Database (PDSS). The PDSS contains a complete track record of school performance and student academic results. Schools are given a role in the SNMPTN selection process as part of the integration of secondary and higher education [2]. Many educational institutions (schools) have difficulty in ranking students because there are a large number of alternatives selected for ranking. Therefore, in the implementation stage of SNMPTN, a decision support system is needed to assist the student ranking process.

Decision Support System (DSS) is a software program that helps a manager (decision maker) make decisions. Several previous studies on DSS have been conducted, including Decision Support Systems for The Determination of Cattle with Superior Seeds [3], Decision Support System for "Buleleng Cerdas" Social Fund Recipient Candidates Program [4], and Decision Support Systems used for selection Scholarship recipients [5]. While in this study, DSS was used to assist in determining student rankings, especially among students majoring in science. The subjects were Mathematics, Indonesian, English, Chemistry, Physics and Biology. The WP method was used to determine student rankings. The WP method is one of the Multiple Attribute Decision Making (MADM) methods to complete the decision-making system by taking into account all the criteria and weights. 
Several researchers have applied the WP method with different cases including the selection system for outstanding students with criteria for structure and grammar scores, vocabulary scores, reading scores, writing scores, listening scores, and speaking scores [6]. The application of the WP Method was also implemented in the Selection of the Best Graduates in Faculty of Engineering, University of Muhammadiyah Purwokerto with criteria for GPA, period of study, maximum $\mathrm{C}$ grade of 1 and no D grade [7]. Also, it was used for granting credit using the WP method at BMT Mu'amalah Sejahtera Kendari with the criteria used for completeness of files, guarantees, income, and type of business [8]. Portfolio evaluation is used if the results of ranking students with the WP approach have the same value. Portfolio evaluation is a collection of evidence of the success of a student or group of students, including the evidence of achievement, abilities, and attitudes [9].

\section{Method}

The form of a decision support system flowchart using the WP method show in Figure 1.

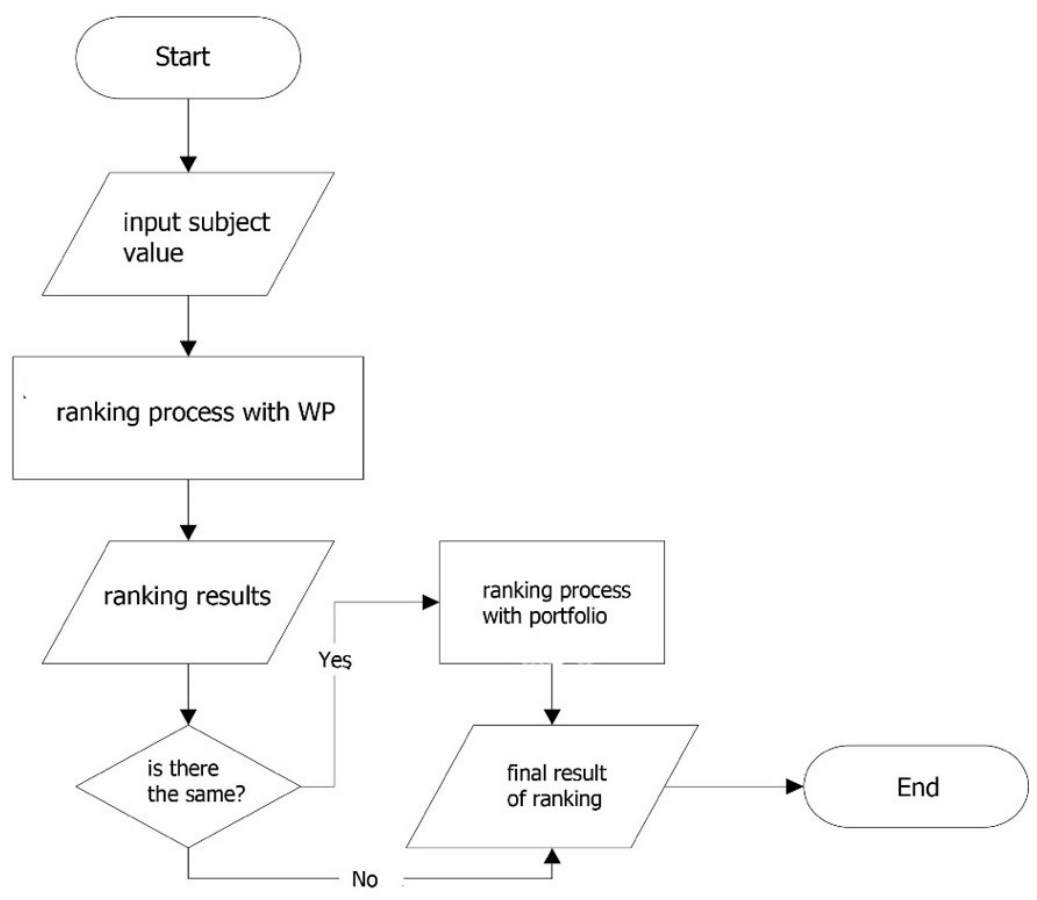

Figure 1. System flowchart

\section{A. Decision Support System (DSS)}

Decision support system is a tool designed to support managers in making decisions that require judgment and cannot be supported by algorithms [10]. The components of the DSS are presented as shown in Figure 2.

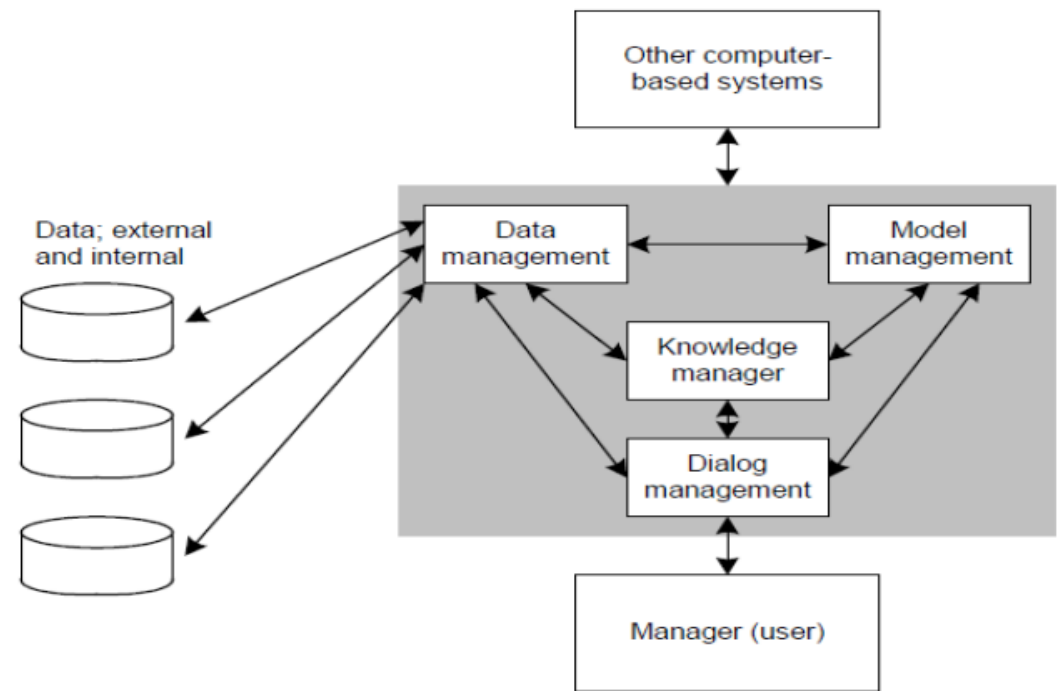

Figure 2. The components of the DSS 
Decision Support Systems have four interrelated subsystems:

1. Data Management consists of databases containing specific data managed by software (DMBS).

2. Model representation is a software that contains statistical models and quantitative models that has the ability to analyze.

3. Knowledge-Based Management is a subsystem that can help other subsystems and has the ability as an independent component.

4. Dialog page/user interface system allows users to connect with other devices and give commands.

The following are the advantages of a decision support system:

1. Able to assist in finding solutions to difficult problems.

2. Have a quick response to unexpected situations.

3. Able to easily and precisely apply a number of different techniques to various configurations.

4. Can improve management control and performance

5. Communication made easier

6. Minimize costs

7. Have more informed decisions

8. Can increase managerial effectiveness by enabling managers to work for shorter periods of time and with less effort

9. Increase analysis productivity

\section{B. Weighted Product Method}

Weighted Product (WP) is a multiplication method for related attribute rankings, where each criterion rating must be raised to the first power with the criteria weight. This process is also known as the normalizing process [11]. The equation (1) expresses the preference for alternative values of $\mathrm{Ai}$

$$
S i=\prod_{j=1}^{n} X i j^{W j}
$$

Information:

$\mathrm{S}:$ Alternative preferences are analogous to vector $\mathrm{S}$

$\mathrm{Xij}$ : The variable value of the alternatives on each attribute

$\mathrm{Wj}$ : Criteria weight value

$\mathrm{n}$ : Number of criteria

i : Alternative value

$\mathrm{j}$ : Value criteria

where $\mathrm{I}=1,2, \ldots . ., \mathrm{m} ; \mathrm{Wj}=1, \mathrm{Wj}$ is a positive rank for the benefit attribute and a negative value for the cost attribute, with the equation (2):

$$
W_{j}=\frac{W_{j}}{\sum W_{j}}
$$

The relative preference of each alternative, using the equation (3):

$$
V_{i}=\frac{\prod_{j=1}^{n}\left(X_{i j}\right)^{W j}}{\prod_{j=1}^{n}\left(X_{j}^{*}\right)^{W j}}
$$

Information

$\mathrm{V}$ : The relative preference of each alternative is analogous to a vector $\mathrm{V}$

$\mathrm{Xij}$ : The variable value of the alternatives on each attribute

$\mathrm{Wj}$ : Criteria weight value

$\mathrm{n}$ : Number of criteria

i : Alternative value

$\mathrm{j}$ : Value criteria

*: The number of criteria that have been assessed on the vector $\mathrm{S}$

\section{Portfolio Assessment}


Portfolios often refer to reports of a person's entire career history [12]. In general, a portfolio is a collection of documents created by individuals, agencies, or other entities with the aim of documenting the progress of a process towards achieving predetermined goals [13]. Portfolios can be considered as a type of physical entity, a pedagogical social mechanism, or an adjective [14]. The physical form of a portfolio is a compilation or document of the work of students (students) which is collected in a bundle, as a tangible form of a portfolio.

In general, a portfolio is a well-organized and well-documented series of student work or student notes. Student assignments, student responses to teacher questions, notes from teacher findings, notes from teacher-student interactions, student activity reports, and student essays or journals can all be included in the portfolio.

Here are some of the advantages of using a portfolio [9]:

1. Can monitor student progress from time to time.

2. Can find out parts of the lesson that are not familiar to students.

3. Can foster student motivation and self-confidence.

4. Can encourage students to take responsibility for their learning.

5. Can correct wrong behavior while studying.

\section{Learning achievement}

The word "achievement" is described by the Popular Scientific Dictionary as "the end result". Learning can be interpreted as a process that allows the emergence or change of a behavior as a result of the development of a primary response, as long as the emergence or change in new behavior is not triggered by a temporary change for any reason. The other side of learning is a relatively permanent increase in the overall activity of the organism as a result of an experience [15].

From several studies about learning achievement, it can be concluded that learning achievement is a collection of several activities that have been carried out by a student who has been through various experiences and is stated in the form of a report. Achievement is the result of student learning efforts, which can be represented in the form of numbers, letters, or sentences that represent the results [16].

\section{Results and Discussion}

At first the user (school operator) inputs the values that are the criteria and the student's portfolio scores. Furthermore, the process of ranking of the student learning achievement was done by applying the WP method. After the ranking process was completed, we checked whether there were the same student ranking (ranking) results. If none were the same, then the final result was a ranking. But if there were the same, the next stage was an assessment based on the student's portfolio value.

We obtained learning achievement data from 127 students. The school had difficulty in determining student rankings, because the distribution of several subject values had the same value. The criteria and preference weights for each criterion are presented in Table 1.

Table 1. Preference weights for each criterion

\begin{tabular}{|l|l|c|}
\hline No & Criteria & Weight (W) \\
\hline 1 & Mathematic (C1) & 5 \\
\hline 2 & Indonesian Language (C2) & 5 \\
\hline 3 & English (C3) & 5 \\
\hline 4 & Chemistry (C4) & 5 \\
\hline 5 & Physics (C5) & 5 \\
\hline 6 & Biology (C6) & 5 \\
\hline
\end{tabular}

While the Portfolio Value (C7) was not determined by the weight of preference. The condition of the learning achievement data is as shown in Table 2.

Table 2. Learning achievement data

\begin{tabular}{|l|l|l|l|l|l|l|}
\hline Alternative & $\mathbf{C 1}$ & $\mathbf{C 2}$ & $\mathbf{C 3}$ & $\mathbf{C 4}$ & $\mathbf{C 5}$ & $\mathbf{C 6}$ \\
\hline 1 & 84 & 65 & 65 & 93 & 57 & 66 \\
\hline 2 & 94 & 55 & 65 & 72 & 87 & 65 \\
\hline 3 & 65 & 57 & 58 & 65 & 62 & 65 \\
\hline 4 & 79 & 65 & 65 & 76 & 68 & 57 \\
\hline 5 & 53 & 65 & 65 & 79 & 64 & 65 \\
\hline$\ldots$ & $\ldots$ & $\ldots$ & $\ldots$ & $\ldots$ & $\ldots$ & $\ldots$ \\
\hline 124 & 53 & 92 & 58 & 65 & 65 & 88 \\
\hline
\end{tabular}




\begin{tabular}{|l|l|l|l|l|l|l|}
\hline 125 & 65 & 65 & 97 & 56 & 65 & 97 \\
\hline 126 & 65 & 92 & 53 & 65 & 65 & 91 \\
\hline 127 & 65 & 85 & 93 & 65 & 72 & 65 \\
\hline
\end{tabular}

Furthermore, the weight improvement was run where the initial weight $\mathrm{W}=(5,5,5,5,5,5)$ was made normal so that the total weight was $\mathrm{W}=1$, using equation (2).

$$
\begin{aligned}
& W_{\text {Matematika }}=\frac{5}{5+5+5+5+5+5}=\frac{5}{30}=0,167 \\
& W_{\text {Bahasa_Indonesia }}=\frac{5}{5+5+5+5+5+5}=\frac{5}{30}=0,167 \\
& W_{\text {Bahasa_Inggris }}=\frac{5}{5+5+5+5+5+5}=\frac{5}{30}=0,167 \\
& W_{\text {Kimia }}=\frac{5}{5+5+5+5+5+5}=\frac{5}{30}=0,167 \\
& W_{\text {Fisika }}=\frac{5}{5+5+5+5+5+5}=\frac{5}{30}=0,167 \\
& W_{\text {Biologi }}=\frac{5}{5+5+5+5+5+5}=\frac{5}{30}=0,167
\end{aligned}
$$

We then calculated the Vector S using equation (1). An example of S1 calculation is as follows.

$$
\begin{aligned}
& S_{1}=(84)^{0,167}(65)^{0,167}(65)^{0,167}(93)^{0,167}(57)^{0,167}(66)^{0,167} \\
& S_{1}=70,632
\end{aligned}
$$

The complete calculation results are as in Table $\mathbf{3}$.

Table 3. Calculation results

\begin{tabular}{|l|l|l|l|l|l|l|l|}
\hline Alternative & $\mathbf{C 1}$ & $\mathbf{C 2}$ & $\mathbf{C 3}$ & $\mathbf{C 4}$ & $\mathbf{C 5}$ & $\mathbf{C 6}$ & $\mathbf{V}$ \\
\hline 1 & 2,0927 & 2,0052 & 2,0052 & 2,1285 & 1,9618 & 2,0103 & 70,632 \\
\hline 2 & 2,1323 & 1,9501 & 2,0052 & 2,0396 & 2,1050 & 2,0052 & 71,784 \\
\hline 3 & 2,0052 & 1,9618 & 1,9675 & 2,0052 & 1,9894 & 2,0052 & 61,907 \\
\hline 4 & 2,0714 & 2,0052 & 2,0052 & 2,0581 & 2,0203 & 1,9618 & 67,937 \\
\hline 5 & 1,9381 & 2,0052 & 2,0052 & 2,0714 & 2,0000 & 2,0052 & 64,735 \\
\hline$\ldots$ & $\ldots$ & $\ldots$ & $\ldots$ & $\ldots$ & $\ldots$ & $\ldots$ & $\ldots$ \\
\hline 124 & 1,9381 & 2,1247 & 1,9675 & 2,0052 & 2,0052 & 2,1090 & 68,702 \\
\hline 125 & 2,0052 & 2,0052 & 2,1435 & 1,9560 & 2,0052 & 2,1435 & 72,457 \\
\hline 126 & 2,0052 & 2,1247 & 1,9381 & 2,0052 & 2,0052 & 2,1208 & 70,411 \\
\hline 127 & 2,0052 & 2,0969 & 2,1285 & 2,0052 & 2,0396 & 2,0052 & 73,394 \\
\hline
\end{tabular}

After obtaining the results of the calculation of the vector value from each alternative, the next step was to rank. The results of the student ranking are as shown in Table 4.

Table 4. Student ranking results

\begin{tabular}{|l|l|l|}
\hline No & Alternative & Score \\
\hline 1 & Student_70 & 81,625 \\
\hline 2 & Student_48 & 79,797 \\
\hline 3 & Student_65 & 79,506 \\
\hline
\end{tabular}




\begin{tabular}{|l|l|l|}
\hline No & Alternative & Score \\
\hline 4 & Student_102 & 79,016 \\
\hline 5 & Student_59 & 77,456 \\
\hline$\ldots$ & $\ldots$ & $\ldots$ \\
\hline 73 & Student_18 & 68,749 \\
\hline 74 & Student_109 & 68,749 \\
\hline$\ldots$ & $\ldots$ & $\ldots$ \\
\hline 85 & Student_33 & 67,703 \\
\hline 86 & Student_23 & 67,703 \\
\hline$\ldots$ & $\ldots$ & $\ldots$ \\
\hline 124 & Student_64 & 63,305 \\
\hline 125 & Student_73 & 63,022 \\
\hline 126 & Student_3 & 61,907 \\
\hline 127 & Student_14 & 61,687 \\
\hline \multicolumn{2}{|l}{} \\
\end{tabular}

Based on the ranking results, there were 7 students who had the same score, namely: between Siswa_18 and Siswa_109, between Siswa_33 and Siswa_23, and between Siswa_54, Siswa_78 and Siswa 117. So to determine the rank of each student, calculations were done using portfolio assessment. The portfolio value of 7 students who had the same value was shown in Table $\mathbf{5}$.

Table 5. Portfolio value

\begin{tabular}{|l|l|l|l|}
\hline No & Name & V & Portfolio Score (C7) \\
\hline 1 & Student_18 & 68,749 & 63 \\
\hline 2 & Student_109 & 68,749 & 65 \\
\hline 3 & Student_33 & 67,703 & 71 \\
\hline 4 & Student_23 & 67,703 & 65 \\
\hline 5 & Student_54 & 65,000 & 81 \\
\hline 6 & Student_78 & 65,000 & 68 \\
\hline 7 & Student_117 & 65,000 & 65 \\
\hline
\end{tabular}

The equation used to calculate the vector value and the portfolio value was the equation to find the average. An example of calculating vector values and portfolio values is as follows.

$$
\begin{aligned}
& \text { Rata }- \text { rata }=\frac{\sum X i}{\sum n} \\
& \text { Siswa_18 }=\frac{68,749+63}{2}=65,875
\end{aligned}
$$

The results of the complete calculation of vector values and portfolio values are as shown in Table 6.

Table 6. The results of the calculation of the portfolio value

\begin{tabular}{|l|l|l|l|}
\hline No & Name & Score & Ranking \\
\hline 1 & Student_18 & 65,875 & 74 \\
\hline 2 & Student_109 & 66,875 & 73 \\
\hline 3 & Student_33 & 69,351 & 85 \\
\hline 4 & Student_23 & 66,351 & 86 \\
\hline 5 & Student_54 & 73,000 & 116 \\
\hline 6 & Student_78 & 66,500 & 117 \\
\hline 7 & Student_117 & 65,000 & 118 \\
\hline
\end{tabular}


The final value from the results of the calculation of the portfolio assessment was used only to determine the ranking when there was the same vector value from the calculation of the WP and did not change the previous value of the calculation results of the WP.

\section{Conclusion}

The results show that academic achievement was determined by many factors and the number of alternatives chosen to determine the ranking in the SNMPTN stage process. Thus, by implementing a combination of using the weighted product method and portfolio assessment, we could determine the ranking of student achievement.

\section{References}

[1] A. Syafi'i, T. Marfiyanto, and S. Rodiyah, "Studi Tentang Prestasi Belajar Siswa Dalam Berbagai Aspek dan Faktor Yang Mempengaruhi,” J. Komun. Pendidik., vol. 2, no. 2, 2018.

[2] LTMPT, Informasi Seleksi Nasional Masuk Perguruan Tinggi Negeri. Jakarta, 2020.

[3] C. Josaputri, E. Sugiharti, and R. Arifudin, "Decision Support Systems for The Determination of Cattle with Superior Seeds using AHP and SAW Method,” Sci. J. Informatics, vol. 3, no. 2, 2016.

[4] A. Fitri, M. Pradnyana, and G. Darmawiguna, "Decision Support System for 'Buleleng Cerdas' Program Social Fund Recipient Candidates with Analytical Hierarchy Process (AHP) and Simple Additive Weighting (SAW) Method," Sci. J. Informatics, vol. 5, no. 2, 2018.

[5] M. Sutoyo, "Implementation of Model Yager MADM Method for Selection of PPA Scholarship," JUITA, vol. 5, no. 2, 2017.

[6] D. Prabawati, "Pembangunan Sistem Pemilihan Siswa Berprestasi Menggunakan Multiattribute Decision Making Dengan Metode Penyelesaian Weighted Product," Universitas Pendidikan Indonesia, 2002.

[7] D. Yoni and H. Mustafidah, "Application of WP (Weighted Product) Method For Selection of Best Graduate Students In The Engineering Faculty of Universitas Muhammadiyah Purwokerto,” JUITA, vol. 4, no. 1, 2016.

[8] A. Jalil, I. Ningrum, and M. Muchtar, "SPK Pemberian Kredit Menggunakan Metode WP (Weighted Product) Pada BMT Mu'amalah Sejahtera Kendari," semanTIK, vol. 3, no. 1, 2017.

[9] B. Santoso, "Penilaian Portofolio Dalam Matematika," J. Pendidik. Mat., vol. 1, no. 2, 2007.

[10] E. Turban and Aronson, Decision Support Systems and Intelligent Systems. Prentice Hall International: New Jersey, 2001.

[11] S. Kusumadewi, S. Hartati, A. Hardjoko, and R. Wardoyo, Fuzzy Multi-Attribute Decision Making (Fuzzy MADM). Yogyakarta: Graha Ilmu, 2006.

[12] Janet, "Portofolio Sebagai Alternatif Penilaian Autentik dalam Pembelajaran Matematika," in National Science Education Seminar: New Paradigm in Mathematics and Science Education in Order to Enhance the, 2002.

[13] R. Setiamihardja, "Penilaian Portofolio Dalam Lingkup Pembelajaran Berbasis Kompetensi," J. Pendidik. Dasar EduHumaniora, vol. 3, no. 2, 2011.

[14] D. Budimansyah, Model Pembelajaran Dan Penilaian Portofolio. Bandung: PT Ganesindo, 2002.

[15] R. Wahab, Psikologi Belajar. Jakarta: PT Raja Grafindo Persada, 2015.

[16] S. Djamaroh, Strategi Belajar Mengajar. Jakarta: Rineka Cipta, 2002. 